\title{
The Edgerton Structure: A Possible Meteorite Impact Feature in Eastern Kansas
}

\author{
Daniel F. Merriam, ${ }^{1}$ Jianghai Xia, ${ }^{2}$ and John W. Harbaugh ${ }^{3}$ \\ ${ }^{1}$ Univesity of Kansas, 1930 Constant Avenue, West Campus, Lawrence, KS 66047, USA \\ ${ }^{2}$ Kansas Geological Survey, University of Kansas, Lawrence, KS 66047, USA \\ ${ }^{3}$ Department of Geological and Environmental Sciences, Stanford University, Stanford, CA 94305, USA \\ Correspondence should be addressed to Daniel F. Merriam, dmerriam@ku.edu \\ Received 18 March 2009; Accepted 18 October 2009 \\ Recommended by Marek Grad
}

\begin{abstract}
Recognized meteorite impact features are relatively rare in the U.S. Midcontinent region, but recently with increased interest and research, the number has increased dramatically. We add another possibility to the growing list, the Edgerton structure in northwestern Miami County, Kansas. The feature is elliptical $(\sim 5.5 \times 6.5 \mathrm{~km}$, slightly elongated east-west $)$ with radial surface drainage. The feature was first observed on hillshade maps of digitized topography of 7.5 minute quadrangles. Subsequent magnetic profiles show a higher magnetic value in the center of the ellipse with higher values around the edges; this shape is characteristic of an impact feature. Depth to the anomalous body is estimated to be about $1 \mathrm{~km}$, which puts it in the Precambrian crystalline basement under a cover of Paleozoic sediments. There are no deep boreholes in the vicinity and no seismic profiles are available. If it is an impact structure, it will be the second such feature documented in Kansas, the first being the Brenham meteorite crater at Haviland in Kiowa County in southwestern Kansas. It would be older than the other impact structures identified in the Midcontinent-Manson in Iowa, Ames in Oklahoma, Haswell Hole in Colorado, and possibly Belton in Missouri and Merna in Nebraska. There are at least two other prospective impact features in Kansas: the Goddard ring west of Wichita and Garden City ellipse north-west of Garden City.
\end{abstract}

Copyright (C) 2009 Daniel F. Merriam et al. This is an open access article distributed under the Creative Commons Attribution License, which permits unrestricted use, distribution, and reproduction in any medium, provided the original work is properly cited.

\section{Introduction}

Circular, oval, or elliptical features, observed on airphotos, remote-sensed images, topographic quadrangle maps, hillshade maps, or on the ground in the field, may be the result of several independent or combination of factors. The most obvious and spectacular features are sinkholes that form relatively quickly and "buffalo wallows," shallow depressions present in large numbers on the High Plains. More recently, some circular features have been attributed to meteorite impact.

There are at least five causes of physiographic circular features:

(1) erosion widens a valley and then closes the open end giving an illusion of a circular feature, for example, Cheyenne Bottoms in Barton County,
(2) solution of material and collapse of overlying material to form a sinkhole, for example, Old Maids Pool in Wallace County,

(3) meteorite impact feature, for example, Haviland crater (the term crater is used here in the sense of a meteorite impact feature and does not necessarily imply a surface depression) in Kiowa County,

(4) buffalo wallows-formed by animals and enlarged by wind, with many examples on the High Plains [1],

(5) dish-shaped structure with compaction of overlying sediments.

We are interested here only in the meteorite impact features.

There have been speculations for years of possible meteorite impact features in Kansas. In fact, Big Basin and 


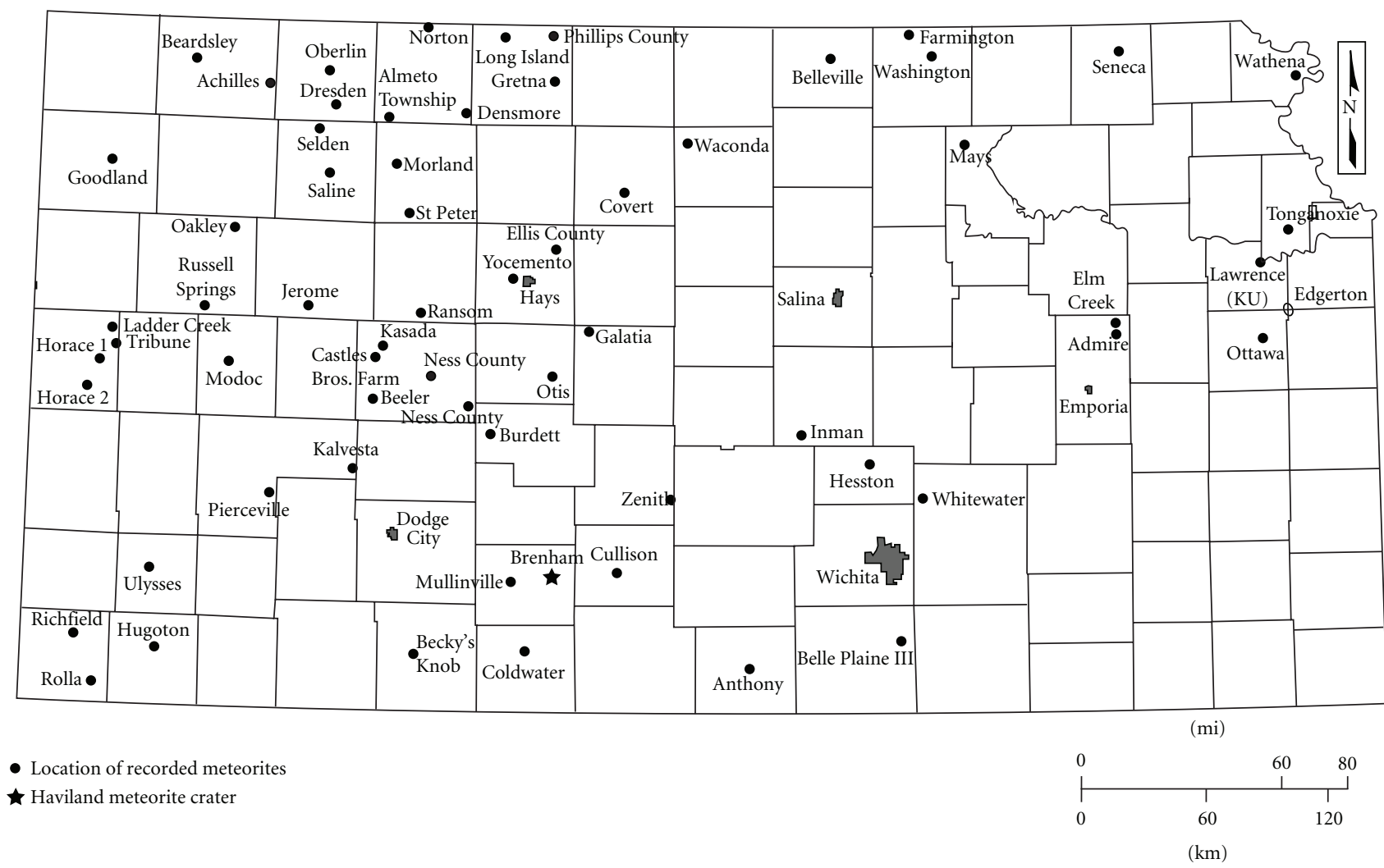

FIGURE 1: Suggested or suspected impact features in Kansas.

Little Basin in Clark County in the southwestern part of the state have been cited as examples (e.g., [2]). Several impact features have been identified and verified in the U.S. Midcontinent, for example, Manson in Iowa (Cretaceous; $[3,4])$, Ames in Oklahoma (Cambrian; [5]), Haswell Hole in Colorado (Precambrian; [6, 7]), and possibly Belton RingFault Complex in Missouri (post-Pennsylvanian; [8]) and Merna in Nebraska (Recent; [9]). So why not in Kansas? Although many meteorites have been found and catalogued in the state, only one meteorite feature has been identified and recorded, the Brenham crater near Haviland in Kiowa County in southwestern Kansas [10].

It is known that some drainage patterns reflect features at depths to the Precambrian basement. Long, straight river valleys follow fractures/faults; for example, segments of the Neosho River Valley and the zigzag course of the Arkansas River are good examples [11]. Therefore, circular and radial drainage patterns on the surface may reflect circular features in the subsurface in Kansas [12]. We suggest that there are several intriguing such features in Kansas recognizable on topographic, hillshaded, and other maps that with detailed study may prove to be impact features (Figure $1 ;[13]$ ).

We have named the feature described here Edgerton (for the small town nearby) in northwestern Miami County in eastcentral Kansas (Figure 1). Edgerton was recognized by its circular nature and surface drainage pattern. A followup magnetic profile is highly suggestive of a circular feature with a rim and central high, which could indicate that it is an impact feature. Unfortunately, no subsurface data or seismic profiles are located close enough to confirm our preliminary identification.

\section{Local Geology}

Surface rocks are the lower part of the clastic Douglas Group and alternating limestone and shale units of the Lansing/Kansas City groups (upper Pennsylvanian) thinly covered by Recent and Pleistocene deposits. Surface geology of Miami County was mapped and described by Newell in 1935 [14] and for Franklin County by Ball et al. in 1963 [15]. Neither study reports anything out of the ordinary in the area of the Edgerton feature. Overlying sedimentary rocks are relatively flat and have relatively low magnetic susceptibility [16].

Two wells drilled in the area in 1944 and 1965, neither reaching the Precambrian surface, reported a normal stratigraphic section for this part of the state. The Pennsylvanian section is underlain by Mississippian limestones and Kinderhook Shale, Viola Limestone and Simpson Group (Ordovician), and Cambro-Ordovician Arbuckle Group carbonates. The total section to the Arbuckle is about $480 \mathrm{~m}$ and the thickness from top of Arbuckle to Precambrian should be about $240 \mathrm{~m}$ [11]; total sedimentary section, then, is on the order of about $700 \mathrm{~m}$ to $800 \mathrm{~m}$.

The interpretation of the Precambrian basement by [17] is that the basement in this part of the state is composed mainly of granite $(1.6 \mathrm{Ga})$ with younger intrusive granite bodies $(1.35 \mathrm{Ga})$. 


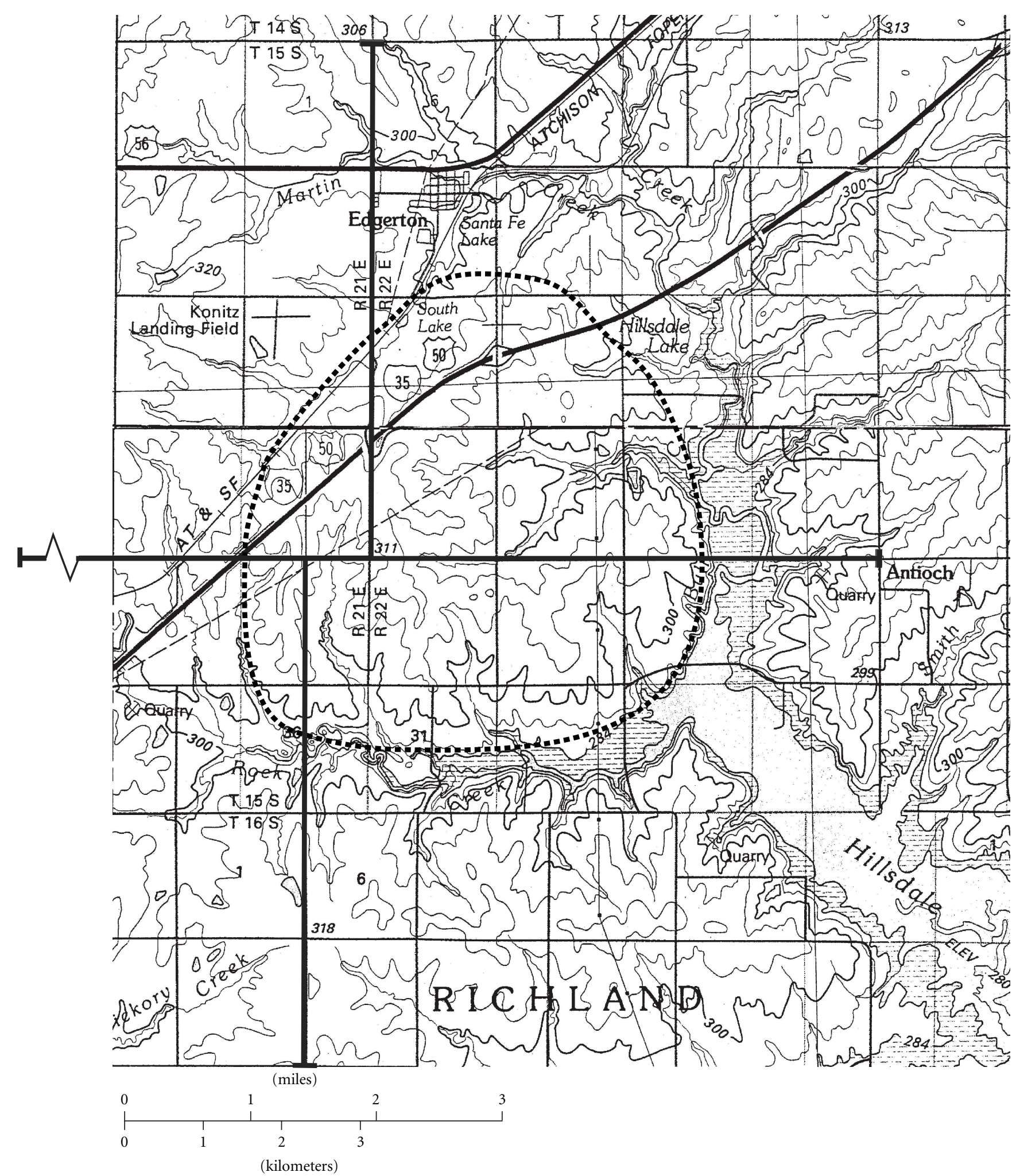

FIgURE 2: Surface topographic expression (a circle with a dash line) and location of magnetic profiles (two solid lines). 


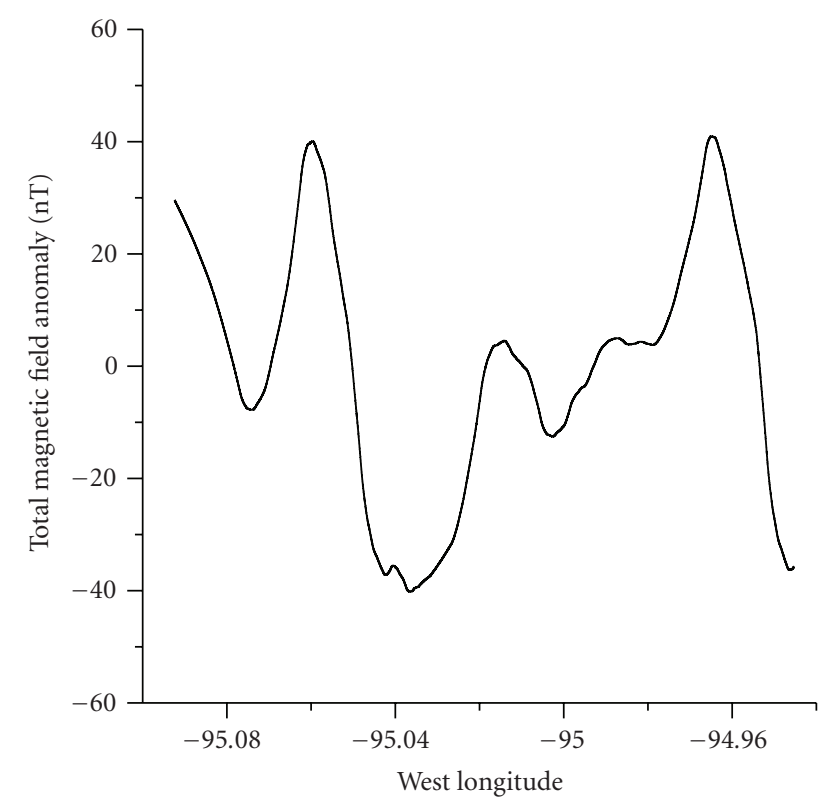

FIGURE 3: Ground magnetic anomalies along east-west line after diurnal correction and spike and linear trend removal.

\section{Edgerton Ring Surface Expression}

It was the topographic ring or elliptical shape on the hillshade map near Edgerton that attracted attention. The slightly elongated east-west feature is approximately $5.5 \times 6.5 \mathrm{~km}$. The features are emphasized by radial drainage with Rock Creek and Bull Creek forming the southern and eastern boundaries (Figure 2).

\section{Geophysical Magnetic Survey}

In December of 2004 surface east-west and north-south magnetic profiles, based on accessibility of county roads, were made across the feature (Figure 2). Total magnetic field was recorded with a Geometrics G858 cesium magnetometer. Data were acquired along a 12.8-km-long east-west line (longitude -95.0281 degrees) at the latitude 38.7229 degrees from the longitude -95.0914 to -94.9441 degrees and a $12.8-\mathrm{km}$ southnorth line near the center of the eastwest line from latitude 38.65 to 38.7821 degrees. Another Geometrics G856 Proton magnetometer was used to measure the diurnal changes of the Earth's field every 10 minutes at a fixed station at the center of the two lines. The maximum diurnal changes during the survey period of time were about $20 \mathrm{nT}$. The normal geomagnetic field in Miami County is 53,505 nT.

The field measurements were corrected for diurnal variation. Magnetic spikes in the field measurements resulting from a highway overpass, a railroad, and utility lines were removed and replaced by the normal earth field value $(53,505 \mathrm{nT})$. Small spikes resulting from culture noises were removed by the wavelet analysis [18]. A regional magnetic field was removed by a linear trend and Figure 3 is the final results of the ground magnetic feature. The maximum change along the line is approximately $80 \mathrm{nT}$. It is interesting

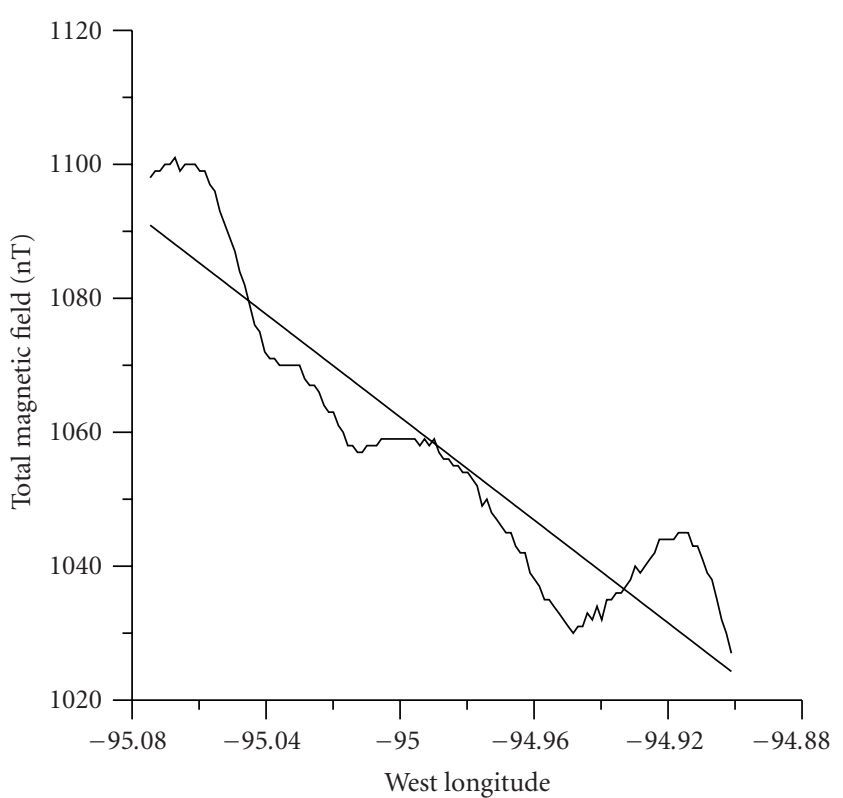

(a)

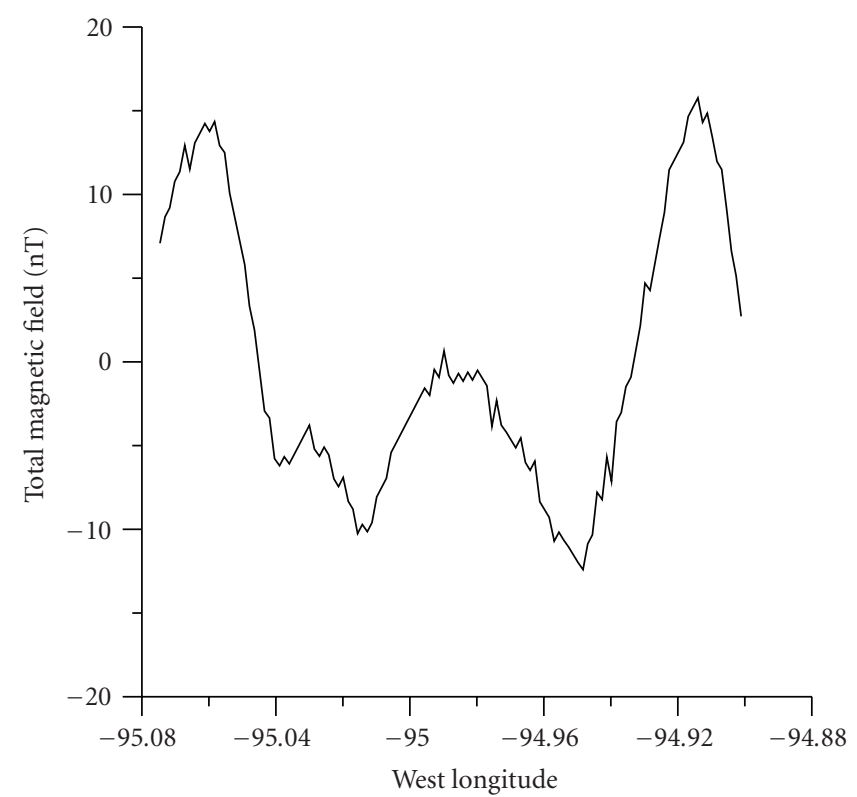

(b)

FIgURE 4: (a) Aeromagnetic data along latitude about N37.7382 degrees with linear regional trend; (b) aeromagnetic anomaly with linear regional field removed.

to note that there are almost identical anomaly highs (40 nT) at positions -94.9649 and -95.0593 degrees and a weak high at the center of the line $(-6 \mathrm{~km})$.

If we use the horizontal cylinder formula to estimate the depth to an anomalous body [19], a maximum depth of about $1 \mathrm{~km}$ is computed for locations of -94.9649 and -95.0593 degrees. These locations suggest edges of the feature. 


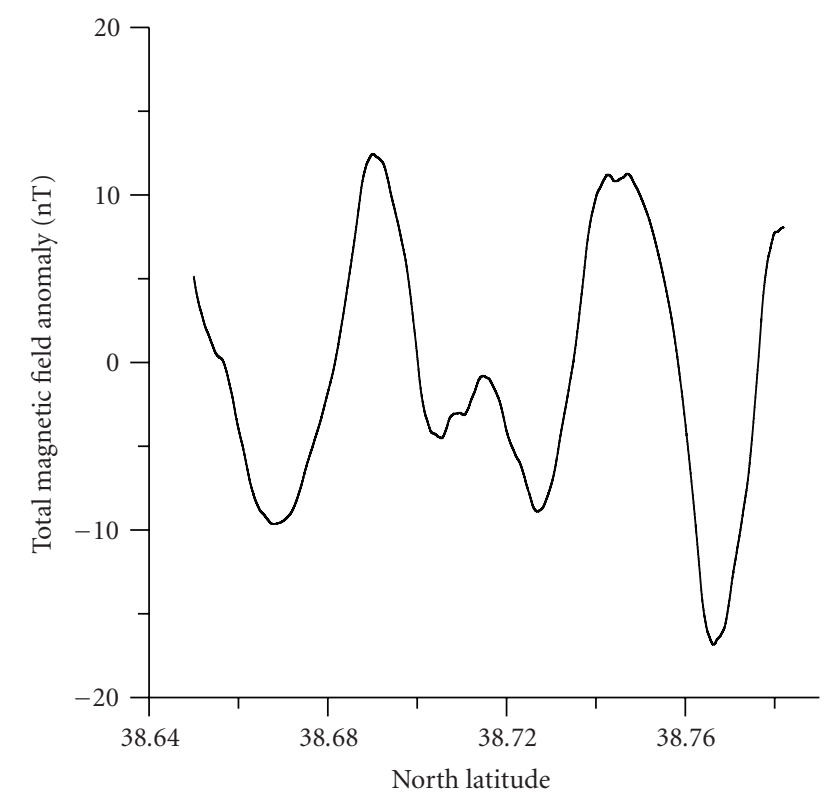

FIGURE 5: Ground magnetic anomalies along southnorth line after diurnal correction, spike removal, and linear trend removal.

To verify the ground survey results, an east-west line of an aeromagnetic survey $(750 \mathrm{~m}$ above the sea level, about $450 \mathrm{~m}$ above the ground surface) along the latitude about N 38.7382 degrees was processed (from [20]). The location of this line is approximately $1.6 \mathrm{~km}$ north of the ground east-west line. Figure 4(a) shows the aeromagnetic data with a straightline representing the regional magnetic field. After removing this regional magnetic field, a residual magnetic anomaly was obtained (Figure 4(b)). The shape of this residual anomaly mimics the ground survey results (Figure 3 ).

The magnetic field surrounding Edgerton is fairly consistent with no other anomalous pattern (e.g., oscillations) evident from available data [21].

The same data-processing procedure was applied to data acquired along the south-north line. The main shape of the residual field (Figure 5) is similar to residual anomalies of the west-east line (Figure 3). There are two anomaly highs: $12 \mathrm{nT}$ at 38.6911 and 38.7446 degrees and a weak high at about the center of the line (38.7138 degree). With the horizontal cylinder formula [19], estimated maximum depths to anomalous bodies are about $1 \mathrm{~km}$ at a location of 38.7138 and $1.6 \mathrm{~km}$ at a location of $9.2 \mathrm{~km}$, respectively.

\section{Geologic Interpretation}

The geological and geophysical evidences suggest the feature is at or near the buried Precambrian surface. From the size of the surface topographic expression and the amount of sediment overburden, it is suggested that the relief on the Precambrian surface is on the order of $90 \mathrm{~m} \mathrm{[12].} \mathrm{A}$ diagrammatic geologic interpretation based on the magnetic survey is given in Figure 6 .

The geophysical signature between Edgerton and Haswell Hole and Ames, which is a presumed and a known meteorite
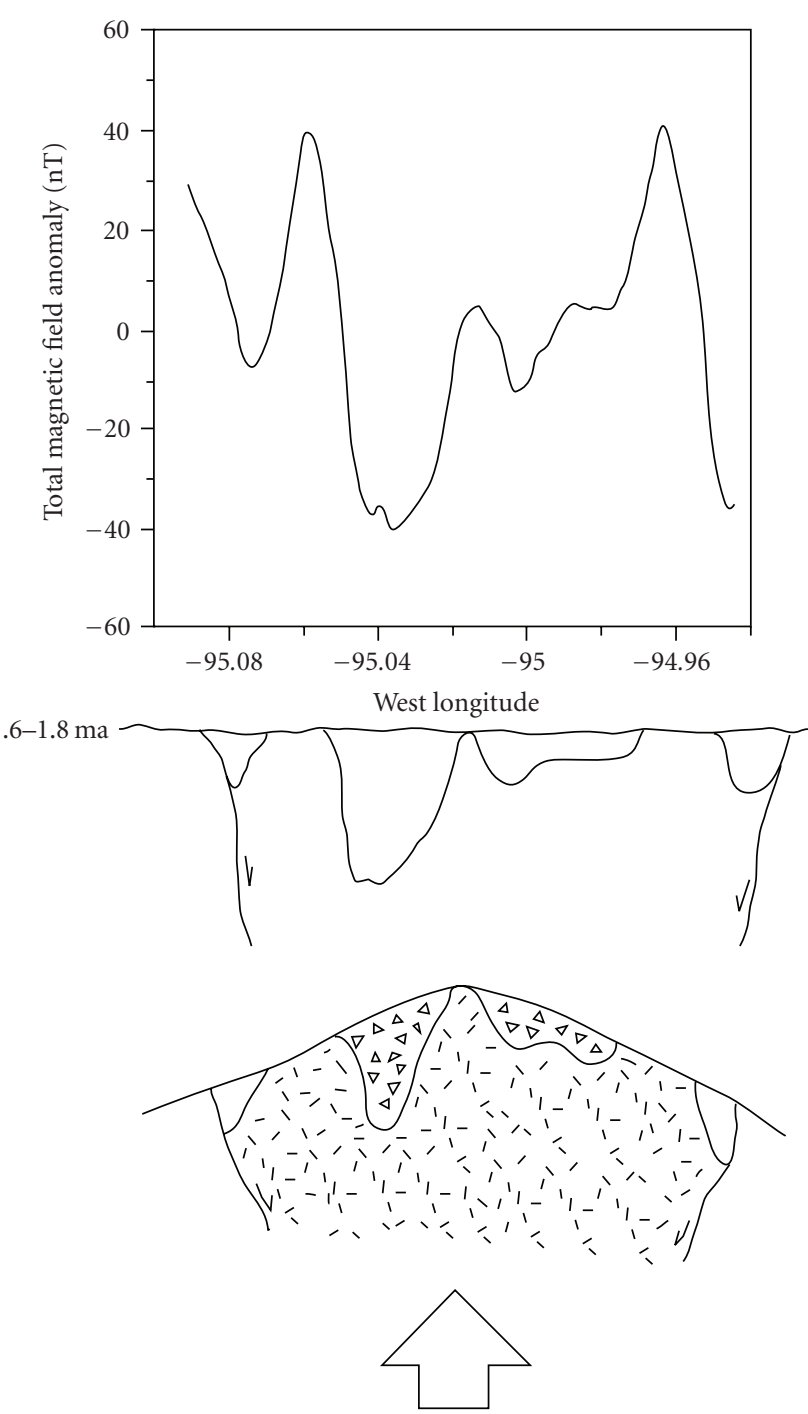

Figure 6: Diagrammatic reconstructed east-west geologic cross section of Edgerton feature. "ma" is the unit of million years.

impact feature, is similar (Table 1). The size and shape of Merna and Big Basin, which are depressions, suggest that they are solution features. Manson, Ames, and Haviland are in a class by themselves as known meteorite impact features. Edgerton and Belton, both unproven impact features, more resemble impact than solution features in their topographic expression. Haswell Hole and Edgerton both are domed and have radial drainage, but many features in eastern Kansas have this shape and are not thought to be impact features. For example, the Big Springs anomaly in northwestern Douglas County is attributed to a Precambrian granite intrusive as is the Beagle anomaly in southwestern Miami County [12]. Both of these anomalies have magnetic highs.

There are a few known intrusive igneous plugs located in Riley and Woodson counties. These small features have been investigated in detail, and their surface expression, size, and age are not similar to Edgerton [11]. 
TABle 1: Comparative data on features discussed here.

\begin{tabular}{lcccccc}
\hline Feature & State & Size $($ diameter in $\mathrm{km})$ & Magnetics & Gravity & Recognized as & Age \\
\hline Manson & IA & 38 & & & impact & $\mathrm{K}$ \\
Haswell & CO & 35 & low & negative & impact & PC \\
Ames & OK & 14 & low & negative & impact & Ord \\
Belton & MO & 3 & & & solution & post-Penn \\
Edgerton & KS & 5 & low & & impact & PC \\
Merna & NE & 1 & & & wind erosion & Recent \\
Big Basin & KS & 1.3 & & solution & Pleisto \\
Haviland & KS & 0.4 & & impact & Recent \\
\hline
\end{tabular}

\section{Summary}

There are two possible scenarios that can be made on the limited amount of data: (1) the impact on the Precambrian surface could have created the topographic relief on the surface, or (2) the impact feature could have been beveled and an intrusive body could have been emplaced in the crust weakened by the impact causing the relief. At this time there is no way to tell which scenario is the correct one although we support the second one (2).

Unfortunately, no boreholes have been drilled in the Edgerton and no seismic profiles are available across the feature. So, an interpretation on whether it is an impact feature will have to await further data.

\section{References}

[1] J. C. Frye, "Origin of Kansas Great Plains depressions," Kansas Geological Survey Bulletin, vol. 86, part 1, pp. 1-20, 1963.

[2] P. J. Cannon, "The Big Basin impact craters of western Kansas (abst.)," in Ames Structure in Northwest Oklahoma and Similar Features: Origin and Petroleum Production, K. S. Johnson and J. A. Campbell, Eds., vol. 100 of Oklahoma Geological Survey Circular, p. 396, University of Oklahoma, Norman, Okla, USA, 1997.

[3] R. R. Anderson, Iowa's Manson Impact Structure: Iowa Geology, vol. 24, Iowa Department of Natural Resources, Des Moines, Iowa, USA, 1999.

[4] J. B. Hartung, J. J. Kunk, and R. R. Anderson, "Geology, geophysics, and geochronology of the Manson impact structure," Geological Society of America, vol. 247, pp. 207-221, 1990.

[5] B. N. Carpenter and R. Carlson, "The Ames meteorite-impact crater," in Ames Structure in Northwest Oklahoma and Similar Features: Origin and Petroleum Production, K. S. Johnson and J. A. Campbell, Eds., vol. 100 of Oklahoma Geological Survey Circular, pp. 104-119, University of Oklahoma, Norman, Okla, USA, 1997.

[6] S. P. Gay Jr., "'Haswell Hole,' a previously unknown impact structure in southeast Colorado," American Association of Petroleum Geologists, vol. 5, p. A51, 1996.

[7] S. P. Gay Jr., "'Haswell Hole,' a previously unknown impact structure in southeast Colorado," in Ames Structure in Northwest Oklahoma and Similar Features: Origin and Petroleum Production, K. S. Johnson and J. A. Campbell, Eds., vol. 100 of Oklahoma Geological Survey Circular, pp. 272-276, University of Oklahoma, Norman, Okla, USA, 1997.
[8] R. J. Gentile, "Geology of the belton quadrangle," Rept. of Invest. 69, Missouri Department of Natural Resources, Jefferson City, Mo, USA, 1984.

[9] W. Dort Jr., E. J. Zeller, L. D. Martin, and U. L. Moody, "Merna Crater-a young impact feature in loess of central Nebraska," in Ames Structure in Northwest Oklahoma and Similar Features: Origin and Petroleum Production, K. S. Johnson and J. A. Campbell, Eds., vol. 100 of Oklahoma Geological Survey Circular, pp. 279-293, University of Oklahoma, Norman, Okla, USA, 1997.

[10] H. H. Nininger and J. D. Figgins, "The excavation of a meteorite crater near Haviland (Kiowa County)," American Journal of Science, vol. 28, no. 16, pp. 312-313, 1934.

[11] D. F. Merriam, “The geologic history of Kansas," Kansas Geological Survey Bulletin, vol. 162, p. 317, 1963.

[12] D. F. Merriam, "Surface expression of buried geologic features in Kansas or a practical example of the metaphor: the princess and the pea," Kansas Academy of Science, vol. 108, no. 3-4, pp. 121-129, 2005.

[13] D. F. Merriam, J. W. Harbaugh, and C. Beiker, "Hillshade maps: a new way to look at the Earth (abst.)," Geological Society of America, vol. 38, no. 7, p. 61, 2006.

[14] N. D. Newell, "The geology of Johnson and Miami counties, Kansas," Kansas Geological Survey Bulletin, vol. 21, part 1, pp. 1-150, 1935.

[15] S. M. Ball, M. M. Ball, and D. J. Laughlin, "Geology of Franklin county, Kansas," Kansas Geological Survey Bulletin, vol. 163, p. 57, 1963.

[16] H. L. Yarger, Regional Interpretation of Kansas Aeromagnetic Data, Kansas Geological Survey Geophysics Series 1, Kansas Geological Survey, University of Kansas, Lawrence, Kan, USA, 1983.

[17] W. R. van Schmus, et al., "Transcontinental Proterozic provinces," in The Geology of North America, Vol. C-2, Precambrian, Conterminous United States, pp. 171-334, Geological Society of America, Boulder, Colo, USA, 1993.

[18] A. Teolis, Computational Signal Processing with Wavelet, Birkhäuser, Boston, Mass, USA, 1998.

[19] L. L. Nettleton, Gravity and Magnetic in Oil Prospecting, McGraw Hill, New York, NY, USA, 1976.

[20] H. L. Yarger, "Major magnetic features in Kansas and their possible geological significance," in Geophysics in Kansas, D. W. Steeples, Ed., vol. 226 of Kansas Geological Survey Bulletin, pp. 197-213, 1989.

[21] H. L. Yarger, R. R. Robertson, J. Martin, K. Ng, R. L. Sooby, and R. L. Wentland, “Aeromagnetic map of Kansas," 1981, Kansas Geological Survey, Map M-16, scale: 1:500,000. 

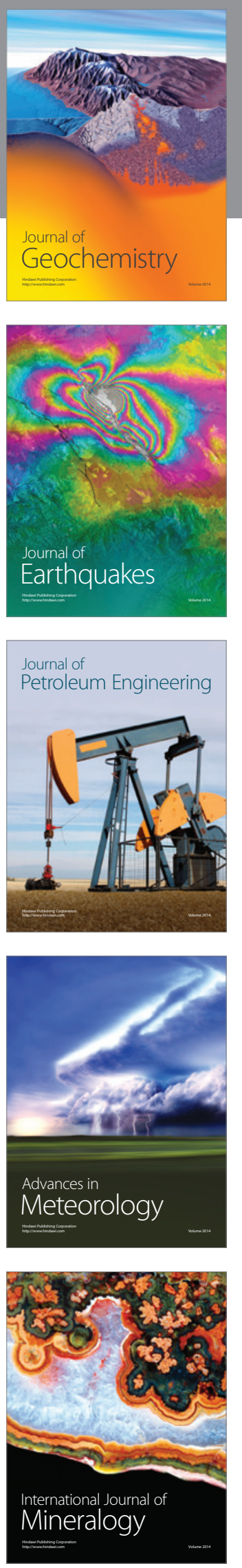
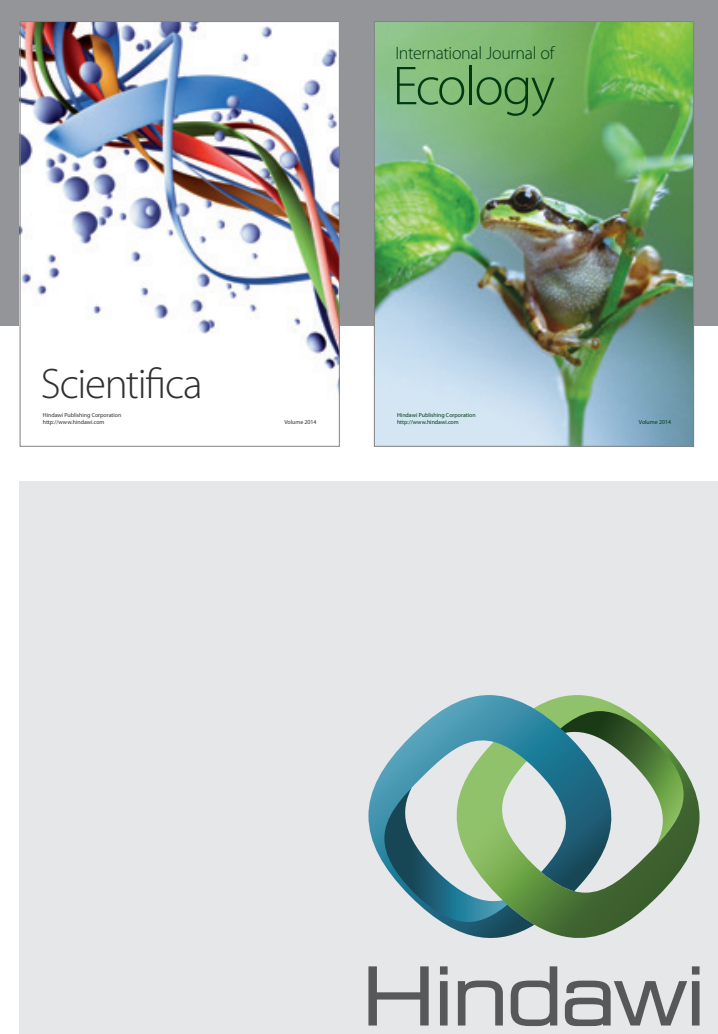

Submit your manuscripts at http://www.hindawi.com
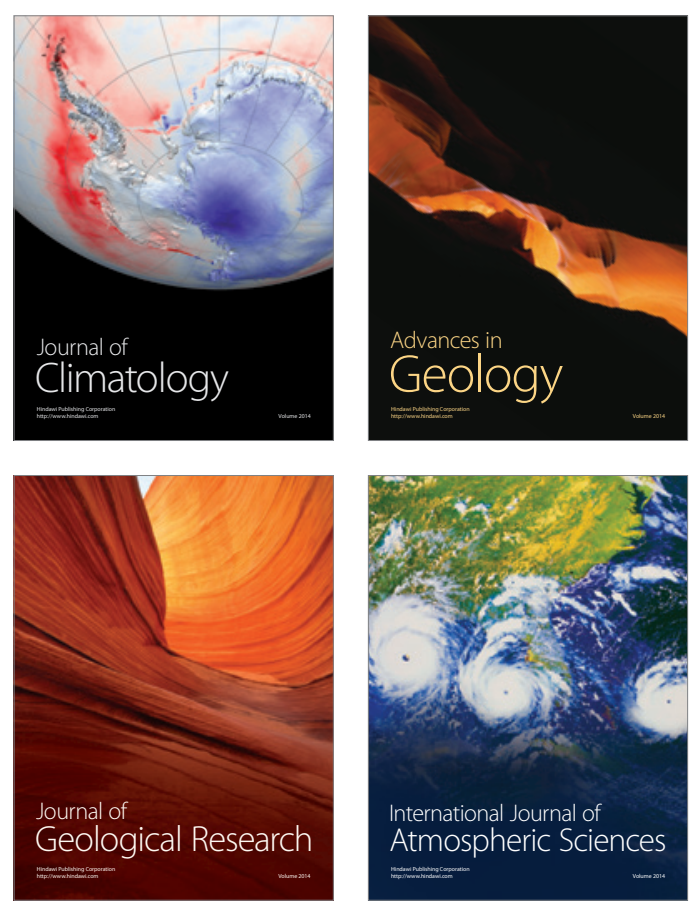
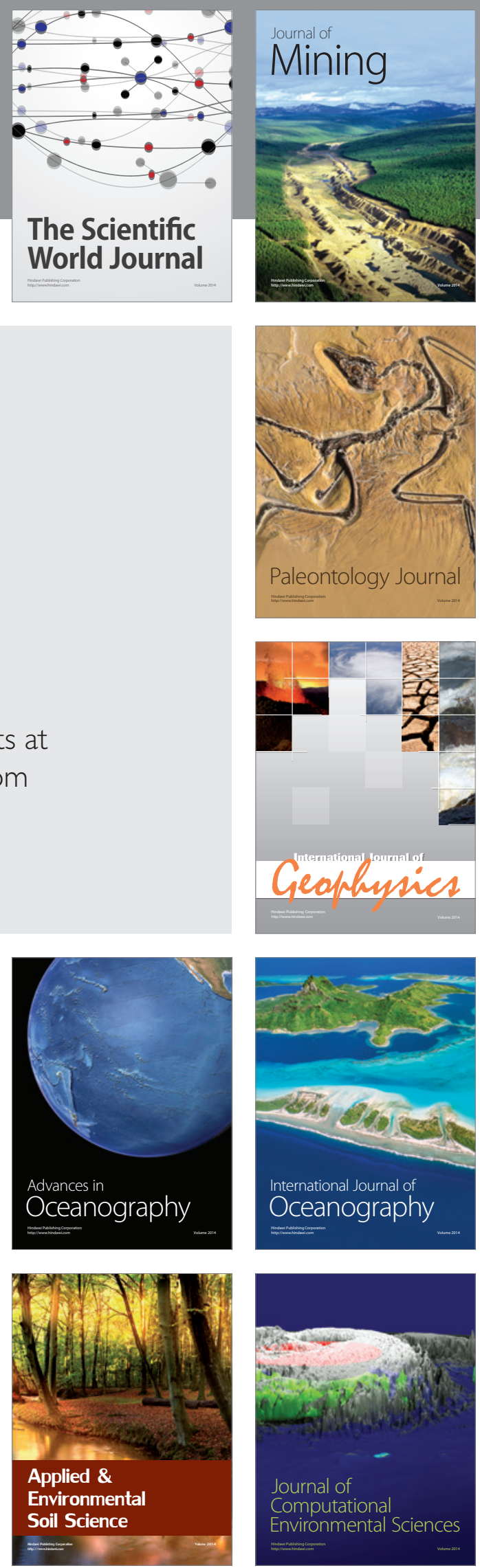